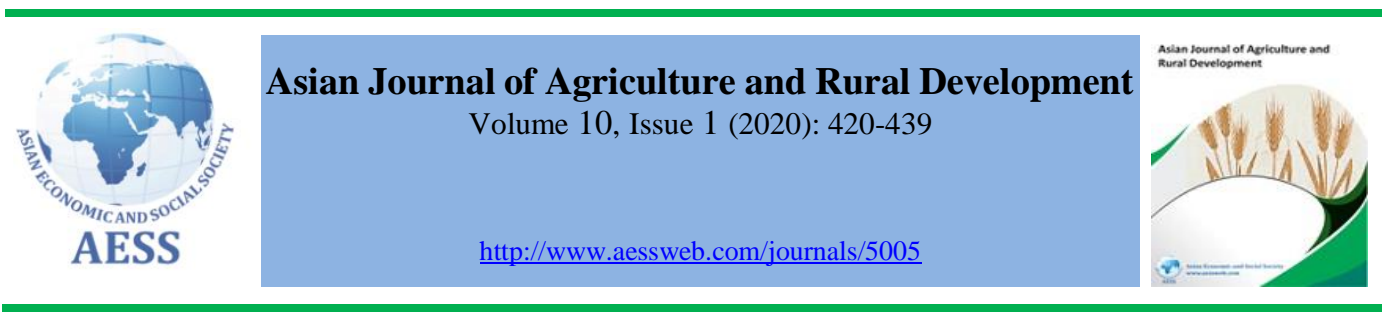

\title{
EVALUATION OF THE POTENTIAL OF JACK BEAN [CANAVALIA ENSIFORMIS (L.) DC.] AND VELVET BEAN [MUCUNA PRURIENS (L.) DC.] AQUEOUS EXTRACTS AS POST-EMERGENCE BIO-HERBICIDES FOR WEED CONTROL IN MAIZE (ZEA MAYS L.)
}

\author{
Rugare, J. T ${ }^{\text {a,b }}$, Department of Agronomy, Stellenbosch University, \\ Pieterse, P. J a , Matieland, 7602, South Africa

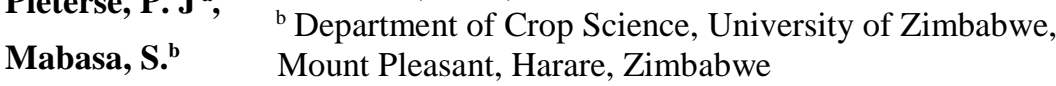

- $₫$ rugarejoy@yahoo.co.uk (Corresponding author)

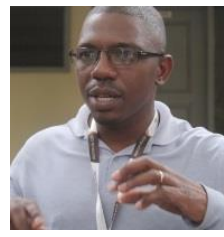

Corresponding author

\section{ARTICLE HISTORY:}

Received: 26-Feb-2020

Accepted: 15-May-2020

Online Available: 19-Jun-

2020

\section{Keywords:}

Allelopathy,

Atrazine,

Bidens pilosa,

Canavalia ensiformis,

Conservation agriculture,

Eleusine indica,

Mucuna pruriens,

Postemergence

\begin{abstract}
The objective of the study was to evaluate the effect of jack bean and velvet bean aqueous extracts when applied post-emergence alone or in combination with half dosage rates of atrazine on goosegrass, beggarticks, and maize. Three potted experiments with fifteen treatments were laid out in a completely randomized design replicated four times and repeated once. The bio-herbicidal treatments were applied to maize at two weeks after crop emergence and on the weeds at the 3-4 leaf stage. Results showed that maize height increased significantly $(\mathrm{p}<0.05)$ across all treatments from 24 to 34 days after crop emergence (DACE). Maize chlorophyll content significantly $(\mathrm{p}<0.05)$ increased from 24 to 34 DACE in all the treatments. In contrast, dry weight, height, and chlorophyll content of goosegrass were significantly $(p<0.05)$ reduced by all treatments. The height of beggarticks was not significantly $(p>0.05)$ affected while chlorophyll content and dry weight were significantly $(\mathrm{p}<0.05)$ reduced by all treatments. All the treatments caused complete weed control at 6 and 10 DAS in beggarticks and goosegrass, respectively. It was concluded that velvet bean and jack bean aqueous extracts are phytotoxic to weeds of divergent morphology.
\end{abstract}

\section{Contribution/ Originality}

The study demonstrated the post-emergence effect of aqueous extracts of jack bean (Canavalia ensiformis) and velvet bean (Mucuna pruriens) on goosegrass (Eleusine indica) and beggarticks (Bidens pilosa).

DOI: 10.18488/journal.1005/2020.10.1/1005.1.420.439

ISSN (P): 2304-1455/ISSN (E):2224-4433

How to cite: Rugare, J. T., Pieterse, P. J., \& Mabasa, S. (2020). Evaluation of the potential of jack bean [Canavalia ensiformis (L.) DC.] and velvet bean [Mucuna pruriens (L.) DC.] aqueous extracts as postemergence bio-herbicides for weed control in maize (Zea mays L.). Asian Journal of Agriculture and Rural Development, 10(1), 420-439. 


\section{INTRODUCTION}

Conservation agriculture (CA) is a farming system involving minimal soil disturbance, permanent soil cover through crop residue retention, and rational use of crop rotations (Harrington and Erenstein, 2005; Hobbs, 2007). The adoption rate of CA in the smallholder sector in sub-Saharan Africa (SSA) is still very low despite all the positive benefits offered by this farming system. One of the key impediments to widespread CA adoption is weed management (Jat et al., 2012). The majority of the resource-poor farmers in the developing world rely mainly on hand weeding despite this method being laborious and expensive resulting in a significant reduction in the size of the fields being put to use for crop production (Khan et al., 2012; Mashingaidze et al., 2012; Rugare and Mabasa, 2013). Consequently, delayed weeding coupled with serious labour bottlenecks in the smallholder sector results in low productivity because farmers fail to control weeds in maize during the critical weed-free period of six weeks (Rugare et al., 2019).

The success of CA hinges on the use of herbicides for weed control because weed control with tillage is not possible. Moreover, chemical weed control is a generally faster and more effective way of managing high populations of difficult to control weeds commonly encountered in reduced tillage systems (Mendes and Rezende, 2014). Permanent soil cover with a layer of mulch of retained crop residues is one of the underpinning principles of CA. Derpsch (2008) reported that permanent soil cover has been a key factor for having success in reduced tillage systems in South America. Experience in other countries including Zimbabwe has shown that reduced tillage without residue retention results in poor yields (Ashburner, 1984; Wall, 1999; Sayre et al., 2006). However, the presence of a thick layer of mulch at the time of planting has made the use of soil-applied herbicides practically unfeasible. This is because the presence of mulch at the time of planting intercepts $15-80 \%$ of pre-emergence herbicides thereby preventing herbicide activation to form an herbicide seal, a process which is key in ensuring the effectiveness of soil-applied herbicides (Chauran et al., 2012). As a result, post-emergence herbicides play an important role in controlling weeds after crop emergence, especially in cases where the efficacy of pre-emergence herbicides would have been compromised by the presence of a thick layer of mulch at the time of planting. However, the excessive and injudicious use of herbicide families with the same mode of action has exerted selection pressure on weed populations that were previously susceptible to those herbicides (Pieterse, 2010). This has resulted in the development of herbicide resistance in some weed populations. The most commonly used herbicides in reduced tillage systems are non-selective herbicides like paraquat and glyphosate that are used as burndown herbicides. Unfortunately, their future role in weed management is bleak because some of the weeds have developed resistance to these widely used herbicides (Pieterse, 2010).

Furthermore, intensive and continuous use of herbicides raises concerns about the sustainability of soil fertility. Herbicides are reported to cause changes in the cycle of nutrients due to their interaction with various soil types resulting in variation in the activity of soil enzymes (Singh and Ghoshal, 2013). On the other hand, environmentalists are lobbying for significant reductions in the use of synthetic herbicides due to the negative effects that they can have on non-target sites and non-target species resulting in the crop, animal and human injury, especially where herbicides with high mammalian toxicity like alachlor and paraquat are not handled and applied correctly (Razzaq et al., 2012; Farooq et al., 2011).

One possible strategy for managing weeds with reduced or no herbicide input in CA is the use of aqueous extracts of allelopathic plant parts as natural herbicides (Razzaq et al., 2012; Soltys et al., 2013). These extracts can be used alone or in combination with reduced herbicide dosages (Mendes and Rezende, 2014; Razzaq et al., 2012; Miri and Armin, 2013). It has been reported that allelopathic aqueous extracts and herbicide combinations work synergistically or additive resulting in satisfactory weed control, considerable monetary savings, and less pollution (Cheema et al., 2005; Razzaq et al., 2012). Al-Obaidi and Alsaadawi (2015) postulated that the use of synthetic 
herbicides can be reduced by $50-70 \%$ when they are tank-mixed with aqueous extracts of sorghum [Sorghum bicolor (L.) Moench] in many field crops including maize. A mixture of allelopathic extracts of sorghum, sunflower (Helianthus annuus L.), and mulberry (Morus rubra L.) combined with atrazine at half dosage rates showed $70-75 \%$ suppression of weed density and dry weight concomitantly resulting in a maize yield increase of $31 \%$ (Khan et al., 2012). It has been reported that the green manure cover crops (GMCCs) jack bean [Canavalia ensiformis (L.) DC.] and velvet bean [Mucuna pruriens (L.) DC.] are sources of potent allelochemicals (Fujii, 1999; Nishihara et al., 2005; Santos et al., 2010; Mendes and Rezende, 2014; Silva and Rezende, 2016). Studies of jack bean extracts have so far been limited to evaluating them using broad-leaved weeds as test species and to our knowledge have never been tested on pernicious grass weed species. Nishihara et al. (2005) confirmed the presence of the allelochemical L-3-[3, 4-dihydroxyphenylalanine (LDOPA)] in velvet bean leaves and roots. There is a paucity of information on the possible role of velvet bean aqueous extracts as post-emergence bio-herbicides for the control of weeds of divergent morphology.

Whilst the use of atrazine in Europe is prohibited (Helling et al., 1988) and its use in other countries like South Africa is declining, it remains one of the key herbicides that are being used in both large scale and small scale arable crop production in Zimbabwe. The use of atrazine in maize (Zea mays L.)-legume rotations in Zimbabwe is likely to increase in CA since research done in several environments demonstrated that $1.8 \mathrm{~kg} \mathrm{ha}^{-1}$ active ingredient (a.i) of atrazine that is recommended in maize does not affect soya bean (Glycine max L.) grown 12 months following herbicide application in the same field (Muoni et al., 2014). This is contrary to conventional tillage where broad-leaved crops susceptible to atrazine can only be safely grown after 18 months from the date of atrazine application (Reinhardt, 1995). Keeping in view the potential of allelopathy in weed management, studies were carried out to evaluate the efficacy of postemergence applications of jack bean and velvet bean leaf, stem, and root aqueous extracts on weed control efficacy as single treatments or in mixture with reduced dosage rates of atrazine. In anticipation of the possibility of using extracts of these cover crops in maize production, their injurious effects on this staple crop were also evaluated.

\section{MATERIALS AND METHODS}

\subsection{Study site}

Greenhouse pot experiments were conducted at the University of Zimbabwe's Crop Science Department between January and June 2017. The University of Zimbabwe (UZ) is located at 1523 $\mathrm{m}$ altitude, $17.78^{\circ} \mathrm{S} ; 31.05^{\circ} \mathrm{E}$ and is in Ecological region $2 \mathrm{a}$. This site receives annual rainfall ranging from 700 to $1000 \mathrm{~mm}$ with an average summer temperature of $25^{\circ} \mathrm{C}$.

\subsection{Extract preparation}

The cover crops, jack bean, and velvet bean that were used in the study were grown under irrigation in a field at the UZ Crop Science Department between September and December 2017. The cover crops were grown in UZ red soil (clay 18\%, silt 16\%, and sand 66\%) and were harvested at the flowering stage (approximately 120 days after planting). After harvesting the plants were separated into leaves, stems, and roots. The different plant parts were chopped into $20 \mathrm{~mm}$ pieces before being air-dried in the greenhouse for two weeks after which they were oven-dried for 48 hours at $80{ }^{\circ} \mathrm{C}$. The dried tissues were ground separately into a fine powder using a hammer mill grinder and the powder was stored in khaki paper envelopes under room temperature for between two and three days after which they were used to make aqueous extracts. Fifty grams of each of the plant tissues were soaked separately in one liter of distilled water and left to stir mechanically using an orbital shaker at 100 revolutions per minute for 24 hours. The solution was then strained through four layers of cheesecloth to remove all the solid material before being centrifuged for 15 minutes at $4000 \mathrm{rpm}$. The resultant supernatant was kept in the refrigerator at $4^{\circ} \mathrm{C}$ until further use. Goosegrass seeds used in the experiment were harvested at Henderson Weed Research in February 
2016 whilst the blackjack seeds were harvested in the UZ Crop Science Department fields in June 2016. Since blackjack produces dimorphic seeds with different germination requirements (Amaral and Takaki, 1998), its short dormant achenes (seeds) were removed and only the non-dormant long achenes were used in this study. Maize variety SC403 which is an early maturing and droughttolerant variety, purchased from SEEDCO was used in the maize bioassay.

\subsection{Experimental design and treatments}

The bioassays for goosegrass, blackjack, and maize were conducted separately in a greenhouse. The experiments were laid out in a Completely Randomised Design (CRD) with fifteen treatments that were replicated four times. The bioassays were repeated once. The treatments were compared against three controls (a) where nothing was sprayed and (b) atrazine $47 \% \mathrm{~g} \mathrm{~L}^{-1}$ a.i recommended full dose (3.5 1/ha) or (c) atrazine half dose $(1.75 \mathrm{l} / \mathrm{ha})$. The treatments used are described in Table 1 .

\section{Table 1: Treatments used in the experiments}

\section{Treatment Description}

1. Control (nothing was sprayed)

2. $114.5 \mu \mathrm{L}$ active ingredient (a.i.) atrazine in $10 \mathrm{ml}$ of distilled water

3. $56.5 \mu \mathrm{L}$ (a.i) atrazine in $10 \mathrm{ml}$ of distilled water

4. $5 \mathrm{ml} 5 \% \mathrm{wv}^{-1}$ velvet bean leaf $+56.5 \mu \mathrm{L}$ (a.i.) atrazine in $5 \mathrm{ml}$ of distilled water

5. $10 \mathrm{ml} 5 \% \mathrm{wv}^{-1}$ velvet bean leaf extract

6. $5 \mathrm{ml} 5 \% \mathrm{wv}^{-1}$ velvet bean root extract $+56.5 \mu \mathrm{L}$ (a.i.) atrazine in $5 \mathrm{ml}$ of distilled water

7. $10 \mathrm{ml} 5 \% \mathrm{wv}^{-1}$ velvet bean root extract

8. $5 \mathrm{ml} 5 \% \mathrm{wv}^{-1}$ velvet bean stem extract $+56.5 \mu \mathrm{L}$ (a.i.) atrazine in $5 \mathrm{ml}$ of distilled water

9. $10 \mathrm{ml} 5 \% \mathrm{wv}^{-1}$ velvet bean stem extract

10. $5 \mathrm{ml} 5 \% \mathrm{wv}^{-1}$ jack bean leaf extract $+56.5 \mu \mathrm{L}$ (a.i.) atrazine in $5 \mathrm{ml}$ of distilled water

11. $10 \mathrm{ml} 5 \% \mathrm{wv}^{-1}$ jack bean leaf extract

12. $5 \mathrm{ml} 5 \% \mathrm{wv}^{-1}$ jack bean root extract $+56.5 \mu \mathrm{L}$ (a.i.) atrazine in $5 \mathrm{ml}$ of distilled water

13. $10 \mathrm{ml} 5 \% \mathrm{wv}^{-1}$ jack bean root extract

14. $5 \mathrm{ml} 5 \% \mathrm{wv}^{-1}$ jack bean stem extract $+56.5 \mu \mathrm{L}$ (a.i.) atrazine in $5 \mathrm{ml}$ of distilled water

15. $10 \mathrm{ml} 5 \% \mathrm{wv}^{-1}$ jack bean stem extract

Note: Atrazine treatments are based on the recommended dosage of 1.75 liters (a.i) ha ${ }^{-1}$ in maize, whilst the extracts dosages used to translate to $200 \mathrm{~L} \mathrm{ha}^{-1}$ of $5 \% \mathrm{wv}^{-1}$ of aqueous extracts of either jack bean or velvet bean tissues

\subsection{Experimental procedure for weed bioassays}

The chemical and physical properties of the soil that was used in the pot experiments are presented in Table 2.

Table 2: Chemical and physical properties of soil

\begin{tabular}{|c|c|c|c|c|c|c|c|c|c|c|c|}
\hline $\begin{array}{l}\text { Clay } \\
(\%)\end{array}$ & $\begin{array}{c}\text { Sand } \\
(\%)\end{array}$ & $\begin{array}{l}\text { Silt } \\
(\%)\end{array}$ & $\begin{array}{c}\mathbf{p H} \\
\left(\mathrm{CaCl}_{2}\right)\end{array}$ & $\begin{array}{c}\text { Moisture } \\
(\%)\end{array}$ & $\begin{array}{c}\text { Organic } \\
\text { carbon } \\
(\mathrm{g} / \mathrm{kg})\end{array}$ & $\begin{array}{c}\text { Organic } \\
\text { matter } \\
(\%)\end{array}$ & $\begin{array}{c}\text { CEC } \\
(\text { me \%) }\end{array}$ & $\begin{array}{c}\mathrm{Ca} \\
(\mathrm{me} \%)\end{array}$ & $\begin{array}{c}\text { Mg } \\
(\text { me \%) }\end{array}$ & $\begin{array}{c}\mathbf{K} \\
(\mathbf{m e} \%)\end{array}$ & $\begin{array}{c}\mathrm{Na} \\
(\mathrm{me} \%)\end{array}$ \\
\hline 7 & 5 & 88 & 4.6 & 0.2 & 0.23 & 0.46 & 2.81 & 1.76 & 0.41 & 0.05 & 0.61 \\
\hline
\end{tabular}

me $\%=$ milliequivalents percent

Pots measuring $90 \mathrm{~mm}$ base diameter, top diameter of $105 \mathrm{~mm}$, and a height of $65 \mathrm{~mm}$ were three quarters filled with sandy soil described in Table 2 . One gram of compound $\mathrm{D}\left(7 \% \mathrm{~N}, 14 \% \mathrm{P}_{2} \mathrm{O}_{5}\right.$, $7 \% \mathrm{~K}_{2} \mathrm{O}$ ) was added to each pot as basal fertilizer. Thereafter, five seeds of goosegrass were planted in each pot. Blackjack does not easily germinate in pots so the seeds were pre-germinated on two layers of Munktell Ahlstrom $90 \mathrm{~mm}$ diameter filter paper in $90 \mathrm{~mm}$ diameter Petri dishes in the weed science laboratory at room temperature (average temperature $=25{ }^{\circ} \mathrm{C}$ ). The seedlings 
were then transplanted in the pots and were watered daily with $150 \mathrm{ml}$ of tap water. Care was taken during watering not to apply water on the foliage of plants that had been sprayed with extracts and/or atrazine. Goosegrass and blackjack seedlings were thinned a week after sowing or transplanting leaving three plants and one plant per pot, respectively. Weed seedlings were sprayed with the prospective bio-herbicidal treatments when they had reached the three to four leaf stage to mimic the stage at which farmers usually control weeds in arable fields (approximately 14 days after crop emergence). The application of herbicidal treatments was done using a hand-held sprayer that was calibrated to discharge $10 \mathrm{ml}$ of spray mixture per four pots to achieve a spray rate of 200 $\mathrm{L} \mathrm{ha}{ }^{-1}$. The application of herbicides was done in the morning around at 9 am with outside temperatures ranging between $20^{\circ} \mathrm{C}$ and $23^{\circ} \mathrm{C}$ and the pots were left in the shade for two hours before being returned into the glasshouse. The average daily maximum and minimum greenhouse temperatures were $32^{\circ} \mathrm{C}$ and $17.9^{\circ} \mathrm{C}$, respectively.

\subsection{Experimental procedure for the maize experiment}

Pots of $200 \mathrm{~mm}$ diameter and $175 \mathrm{~mm}$ height were three quarters filled with sandy soil with the characteristics presented in Table 2. The soil in the pots was mixed with $2 \mathrm{~g}$ of Compound D. (8N: $14 \mathrm{P}_{2} \mathrm{O}_{5} ; \mathrm{K}_{2} 0$ ). Thereafter, three maize seeds (SEEDCO variety SC403) were planted in the pots to a depth of $50 \mathrm{~mm}$ after which the pots were watered with tap water to field capacity using a watering can fit with a fine rose. The maize plants in the pots were thinned leaving one healthy plant per pot seven days after sowing. The maize plants were sprayed with different treatments as presented in Table 1 following the same procedure that was used in the weed bioassays. The same maize plants were sprayed twice with the same treatment at 14 days after crop emergence (DACE) and again at 24 DACE. Thereafter, the plants were allowed to grow for ten more days (observational period) after which the experiment was terminated.

\subsection{Data collection}

Height and chlorophyll content data of maize and the two weed species were collected in situ using a Minota Chlorophyll meter (SPAD 502). Maize chlorophyll content and height data were measured twice at 24 DACE and 34 DACE. In goosegrass, chlorophyll data were collected every day starting from the first day after spraying. In blackjack, chlorophyll content recording was done on days 1, 4 and 6 after spraying. The height of the youngest leaf of blackjack and goosegrass was measured daily up to day 4 and 7, respectively. Thereafter, goosegrass and blackjack plants were uprooted gently together with their roots and washed using running tap water to remove soil before being oven-dried for 24 hours to determine the dry weight of the weeds. Visual assessments of the phytotoxicity of the different treatments on weeds were done daily up to the end of the experiments (i.e. 6 and 10 days after application of herbicidal treatments in blackjack and goosegrass, respectively). The visual phytotoxic assessment of the prospective natural herbicides and their combinations with atrazine was done collectively by three people using the Latin American Weed Association (ALAM) visual assessment scale (Mendes and Rezende, 2014) (Table 3). All the treatments were compared to the untreated control (no extracts applied) and the sole atrazine treatments at full and half dosages.

Table 3: Latin America weed association (ALAM) visual assessment Scale

\begin{tabular}{ccc}
\hline Index & Percentage (\%) & Description of the control level \\
\hline 1 & $0-40$ & None or poor \\
2 & $41-60$ & Regular \\
3 & $61-70$ & Sufficient \\
4 & $71-80$ & Good \\
5 & $81-90$ & Very good \\
6 & $91-100$ & Excellent \\
\hline
\end{tabular}




\subsection{Data analysis}

Plant height and chlorophyll content of weeds and maize were subjected to repeated measures analysis of variance (ANOVA) in Genstat 14 whereas weed dry weight data were analysed using one-way ANOVA at a 5\% probability level. Normality was assessed using the Shapiro-Wilk test and appropriate transformations were done where data did not meet the assumptions of ANOVA. Mean separation was done using the Fischer Protected Least significance difference (Lsd) at $\mathrm{p}<0.05$. Data from the visual assessments were analysed in SPSS using the Kruskal Wallis nonparametric test to obtain Mean Ranks and Mean Separation was done using the Mann Whitney U test. Only visual assessment data for day 1, day 5, and day 10 were presented for goosegrass whilst data for day 1, day 5, and day 6 was presented for blackjack. Graphs were drawn using Sigma Plot 10.0 and $\mathrm{R}$ studio.

\section{RESULTS}

\subsection{Maize height}

Repeated measures ANOVA showed that there was no significant interaction $(p>0.05)$ between time and herbicidal treatment on maize height. However, the height of maize plants significantly $(p<0.05)$ increased by $51.7 \%$ from 24 DACE to 34 DACE (Table 4$)$. There were significant $(p<0.05)$ variations on the height of maize sprayed with different herbicidal treatments (Table 4). All the herbicidal treatments significantly $(\mathrm{p}<0.05)$ stimulated maize height compared to the untreated control except the atrazine full dose, velvet bean root, and jack bean + atrazine.

Table 4: Effect of different (bio-) herbicidal treatments on height and chlorophyll (mean of 24 and 34 DACE) content of maize

\begin{tabular}{lcc}
\hline Herbicidal treatment & Height $(\mathbf{m m})$ & Chlorophyll $\left(\mathbf{m m o l}^{-\mathbf{2}}\right)$ \\
\hline Control & $177.6^{\mathrm{a}}$ & 34.25 \\
Atrazine full dose & $193.8^{\mathrm{a}}$ & 36.64 \\
Atrazine half dose & $205.6^{\mathrm{a}}$ & 36.68 \\
Velvet bean leaf + atrazine & $203.1^{\mathrm{a}}$ & 34.25 \\
Velvet bean leaf only & $213.1^{\mathrm{bc}}$ & 36.12 \\
Velvet bean stem + atrazine & $206.6^{\mathrm{a}}$ & 36.76 \\
Velvet bean stem & $192.5^{\mathrm{a}}$ & 33.24 \\
Velvet bean root + atrazine & $199.6^{\mathrm{a}}$ & 34.49 \\
Velvet bean root & $179.5^{\mathrm{a}}$ & 34.21 \\
Jack bean leaf + atrazine & $229.9^{\mathrm{bcd}}$ & 34.29 \\
Jack bean leaf only & $226.9^{\mathrm{bcd}}$ & 34.11 \\
Jack bean stem + atrazine & $228.2^{\mathrm{bcd}}$ & 35.83 \\
Jack bean stem & $176.9^{\mathrm{a}}$ & 33.29 \\
Jack bean root + atrazine & $209.6^{\mathrm{ab}}$ & 37.56 \\
Jack bean root & $214.4^{\mathrm{bc}}$ & 33.58 \\
P- value & 0.006 & 0.681 \\
Lsd & 31.63 & $\mathrm{~ns}$ \\
CV\% & 13.7 & 25.5 \\
& Days after first spraying & \\
24 DACE & $161.9^{\mathrm{a}}$ & $33.01^{\mathrm{a}}$ \\
34 DACE & $245.7^{\mathrm{b}}$ & $36.96^{\mathrm{b}}$ \\
P-value & $<0.001$ & 0.001 \\
Lsd & 7.16 & 2.283 \\
CV\% & 13.7 & 25.5 \\
\hline
\end{tabular}

Means followed by the same letter in the same column are not significantly different at $\mathrm{p}<0.05$ 


\subsection{Maize chlorophyll content}

There was no significant interaction $(\mathrm{p}>0.05)$ between time and herbicidal treatment on maize chlorophyll content and there were no significant ( $p>0.05)$ differences in maize chlorophyll content across all the treatments (Table 4). Nevertheless, maize chlorophyll content significantly $(\mathrm{p}<0.05)$ increased from 24 to 34 DACE across all treatments (Table 4).

\subsection{Goosegrass chlorophyll content}

Repeated measures ANOVA showed a significant interaction $(\mathrm{p}<0.05)$ on the chlorophyll content of goosegrass from 1 DAS to 8 DAS. Chlorophyll content in untreated plants increased significantly from 1 DAS to 8 DAS when complete weed kill was achieved in plants treated with either atrazine and/or cover crop aqueous extracts (Figure 1). Sole atrazine concentrations of $112.5 \mu \mathrm{L}$ and $56.6 \mu \mathrm{L}$ a.i. significantly reduced chlorophyll content of goosegrass compared to treatments with jack bean extracts. The effect of jack bean leaf extracts only and that of a combination of jack bean leaf extracts and atrazine were similar. Velvet bean extracts also significantly reduced chlorophyll content gradually compared to the control. The effect of aqueous extracts of the different tissues of velvet bean was similar. It is noteworthy that velvet bean extracts only started to significantly reduce chlorophyll content at 5 DAS in contrast to atrazine treatments that had already caused a complete reduction in chlorophyll content of goosegrass at 5 DAS. The results show that atrazine was fast-acting on chlorophyll compared to the aqueous extracts of both jack bean and velvet bean or their combination with atrazine.

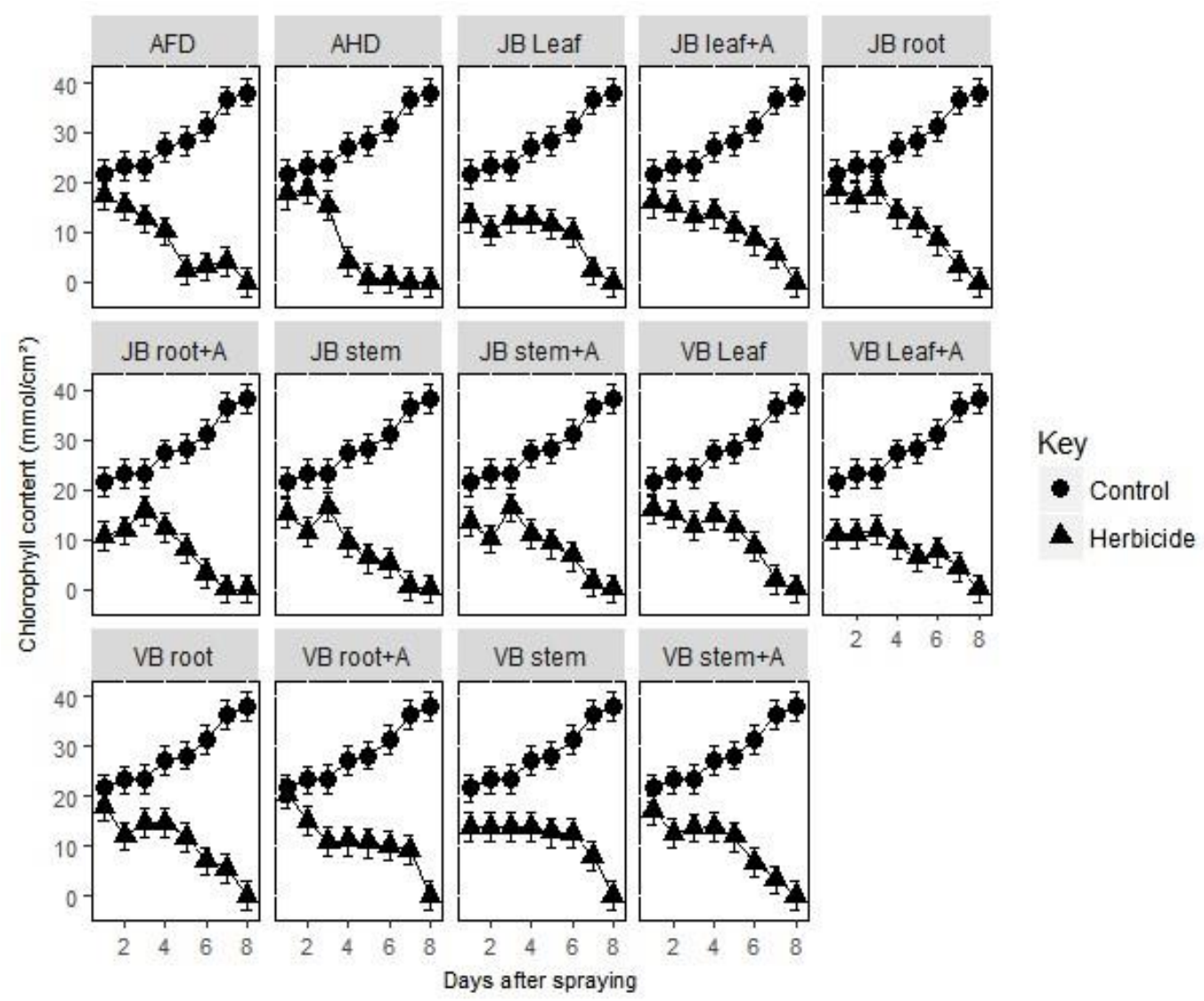

Figure 1: Effect of different post-emergence treatments on chlorophyll content of goosegrass

Error bars indicate interaction standard error of the difference (SED). AFD = atrazine full dose, $\mathrm{AHD}=$ atrazine half Dose, $\mathrm{VB}=$ velvet bean, $\mathrm{JB}=$ jack bean,$+\mathrm{A}=$ plus atrazine half dose 


\subsection{Goosegrass height}

There was a significant $(\mathrm{p}<0.001)$ interaction between time (days after application) and herbicidal treatment on goosegrass height (Figure 2). Untreated plants were significantly taller at 7 DAS compared to all the other treatments. Post-emergence sprays of atrazine full dose, atrazine half dose, velvet bean leaf + atrazine and velvet bean stem + atrazine on goosegrass seedlings caused the plants to collapse resulting in a significant reduction in height by the eighth day compared to the first day of the experiment. On the other hand, the height of the plants that were sprayed with the other treatments and/or atrazine remained the same throughout the experiment.



Figure 2: Effect of post-emergence treatments on the height of goosegrass

Error bars indicate SED. AFD = atrazine full dose, AHD = atrazine half Dose, $\mathrm{VB}=$ Velvet bean, $\mathrm{JB}=$ Jack bean, $\mathrm{A}=$ Atrazine

\subsection{Blackjack chlorophyll content}

There was a significant $(\mathrm{P}<0.001)$ treatment * time interaction on chlorophyll content of blackjack (Figure 3). All the herbicidal treatments significantly reduced blackjack chlorophyll content at both 4 and 6 DAS compared to the first day. It is noteworthy that the majority of tissue extracts when used alone or in combination with atrazine caused complete chlorophyll destruction by day four after the application of post-emergence sprays. 


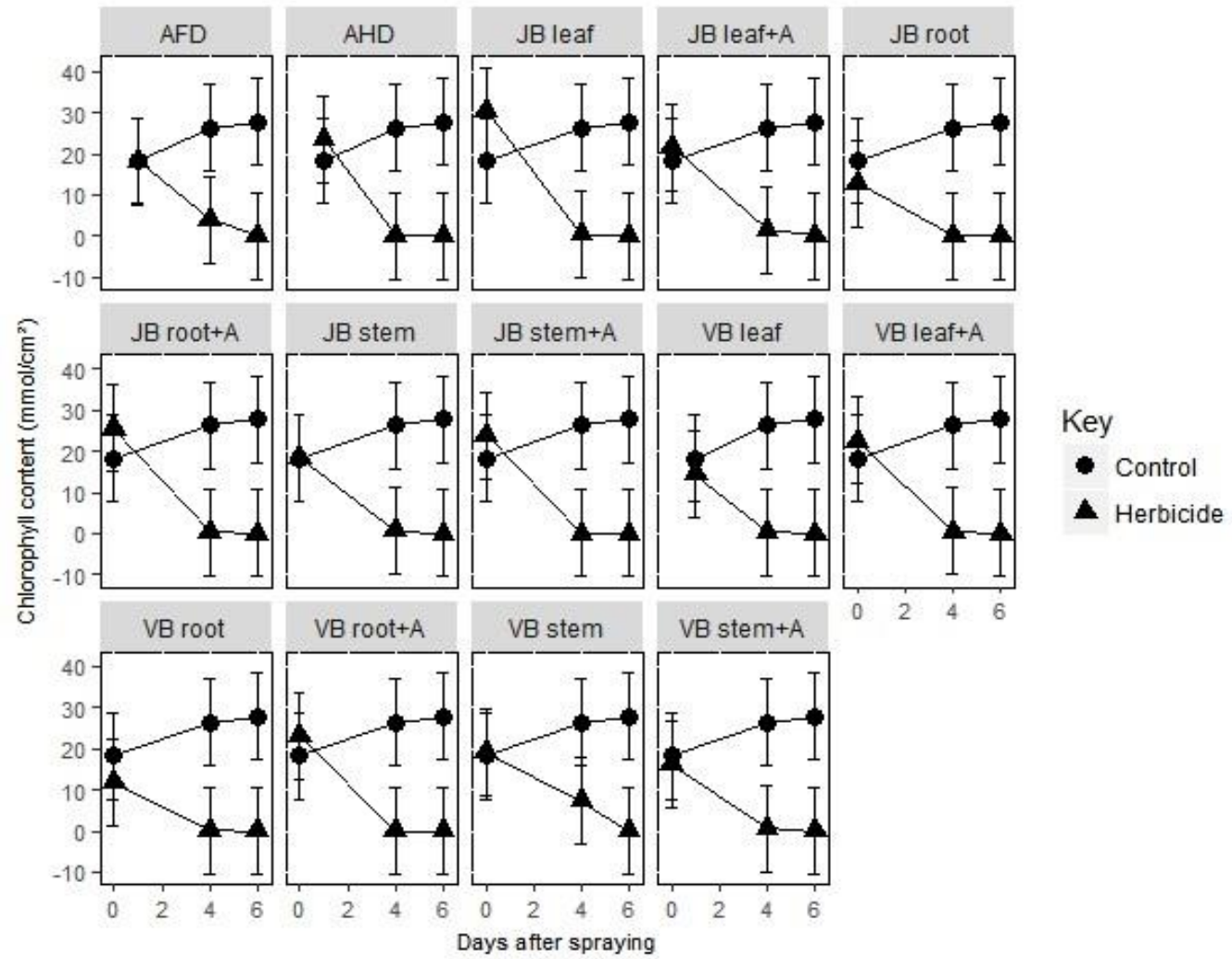

Figure 3: Effect of different post-emergence treatments on chlorophyll content of blackjack

Error bars represent SED. AFD = atrazine full dose, $\mathrm{AHD}=$ atrazine half Dose, $\mathrm{VB}=$ Velvet bean, JB = Jack bean, A = Atrazine

\subsection{Blackjack height}

There was no significant ( $>>0.05)$ interaction between time and treatment on the height of blackjack. No significant ( $p>0.05$ ) change in height was observed from 1-4 DAS (Table 5).

Table 5: Effect of different bio-herbicidal treatments on the height of blackjack

\begin{tabular}{cc}
\hline Days after spraying & Plant height $(\mathbf{m m})$ \\
\hline 1 & 45.87 \\
2 & 45.38 \\
3 & 47.43 \\
4 & 49.13 \\
P-value & 0.292 \\
Lsd & Ns \\
CV\% & 25.0 \\
\hline
\end{tabular}

However, significant $(\mathrm{p}<0.05)$ differences in blackjack height among treatments were observed (Figure 4). Velvet bean treatments did not affect blackjack height compared to the untreated control.

Sole velvet bean extracts of different tissues significantly $(\mathrm{p}<0.05)$ reduced blackjack height compared to the full atrazine dose treatment but did not differ from the atrazine half dose treatment. 
All the jack bean treatments except jack bean root + atrazine treatment significantly reduced blackjack height compared to the controls.

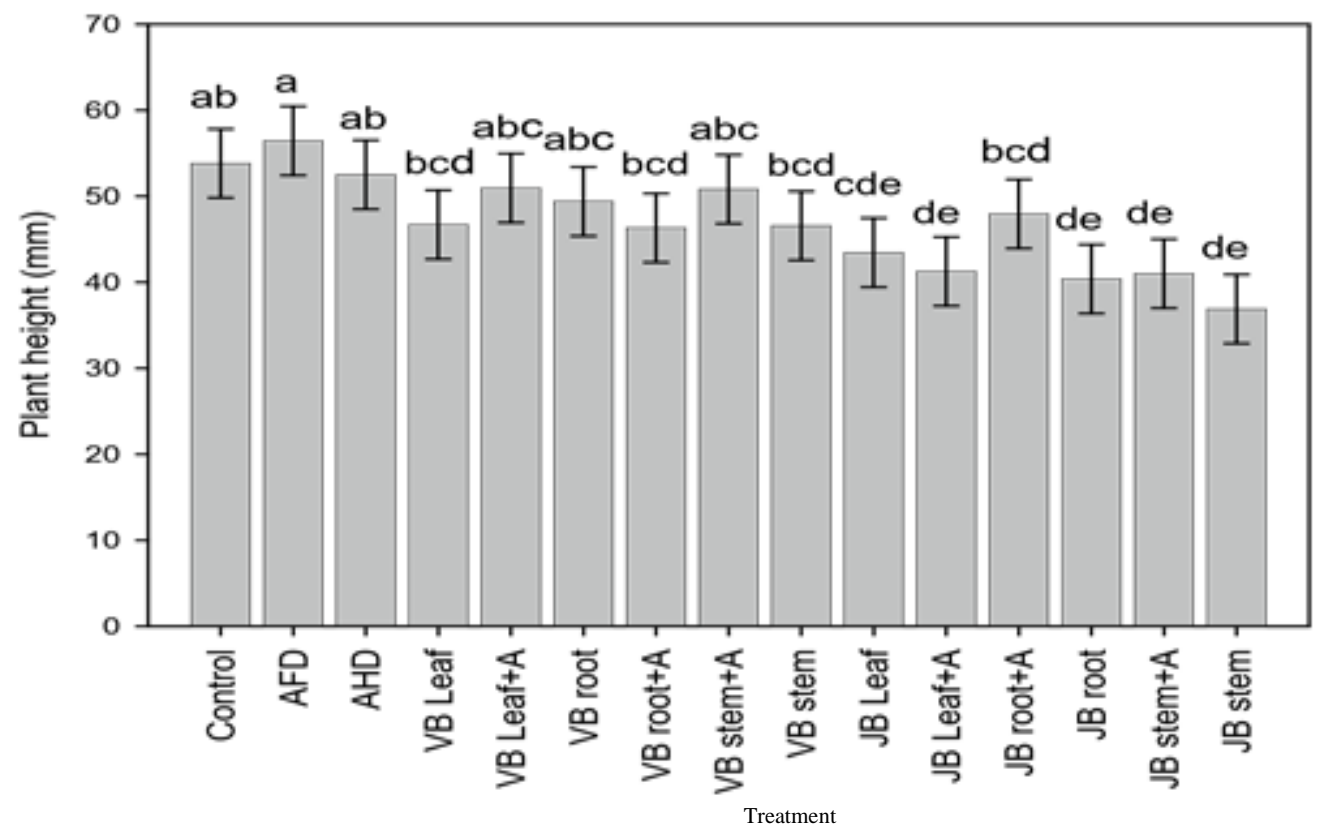

Figure 4: Response of blackjack height to post-emergence sprays of jack bean and velvet bean bio-herbicidal treatments

Error bars indicate SED. AFD = atrazine full dose, $\mathrm{AHD}=$ atrazine half dose, $\mathrm{VB}=$ velvet bean, $\mathrm{JB}$ $=$ jack bean, $\mathrm{A}=$ atrazine

\subsection{Goosegrass and blackjack dry weight}

The effects of velvet bean and jack bean on the dry weight of blackjack and goosegrass are shown in Table 6. All the post-emergence treatments of atrazine and/or cover crop extracts significantly $(\mathrm{p}<0.01)$ reduced the dry weight of blackjack compared to the untreated control. Only the stem extracts of velvet bean significantly reduced blackjack dry weight when applied alone compared to both atrazine controls. Similarly, all the cover crop extract treatments significantly $(\mathrm{p}<0.05)$ reduced the dry weight of goosegrass but they did not differ from the single atrazine treatments.

Table 6: Effect of herbicide and/or aqueous extract post-emergence treatments of jack bean and velvet bean on dry weight (g) of beggarticks and goosegrass at 6 and 10 days, respectively

\begin{tabular}{lcccc}
\hline \multirow{2}{*}{ Treatment } & \multicolumn{2}{c}{ Beggar ticks } & \multicolumn{2}{c}{ Goose grass } \\
& Dry weight $(\mathbf{g})$ & $\begin{array}{c}\text { \% } \\
\text { reduction }\end{array}$ & Dry weight (g) & $\begin{array}{c}\text { \% } \\
\text { reduction }\end{array}$ \\
\hline Control & $0.44(0.101)^{\mathrm{f}}$ & & $0.79(0.588)^{\mathrm{c}}$ & \\
Atrazine full dose & $0.27(0.021)^{\mathrm{bcde}}$ & 79 & $0.41(0.075)^{\mathrm{ab}}$ & 87 \\
Atrazine half dose & $0.29(0.025)^{\mathrm{de}}$ & 75 & $0.49(0.168)^{\mathrm{ab}}$ & 71 \\
Velvet bean leaf + atrazine & $0.31(0.029)^{\mathrm{e}}$ & 71 & $0.39(0.060)^{\mathrm{a}}$ & 90 \\
Velvet bean leaf extract & $0.28(0.022)^{\mathrm{bcde}}$ & 78 & $0.38(0.063)^{\mathrm{a}}$ & 89 \\
Velvet bean root extract + atrazine & $0.26(0.017)^{\mathrm{bcde}}$ & 83 & $0.54(0.295)^{\mathrm{b}}$ & 50 \\
Velvet bean root extract & $0.28(0.024)^{\mathrm{bcde}}$ & 76 & $0.41(0.064)^{\mathrm{ab}}$ & 89 \\
Velvet bean stem extract + atrazine & $0.21(0.011)^{\mathrm{abc}}$ & 89 & $0.45(0.097)^{\mathrm{ab}}$ & 84 \\
Velvet bean stem extract & $0.15(0.010)^{\mathrm{a}}$ & 90 & $0.41(0.071)^{\mathrm{ab}}$ & 88 \\
\hline
\end{tabular}




\begin{tabular}{lcccc}
\hline Jack bean leaf + atrazine & $0.21(0.014)^{\text {abc }}$ & 86 & $0.42(0.087)^{\mathrm{ab}}$ & 85 \\
Jack bean leaf extract & $0.26(0.018)^{\mathrm{bcde}}$ & 82 & $0.38(0.063)^{\mathrm{a}}$ & 89 \\
Jack bean root extract + atrazine & $0.28(0.017)^{\text {cde }}$ & 83 & $0.44(0.067)^{\mathrm{ab}}$ & 89 \\
Jack bean root extract & $0.26(0.013)^{\text {bcde }}$ & 87 & $0.36(0.054)^{\mathrm{a}}$ & 91 \\
Jack bean stem extract + atrazine & $0.23(0.027)^{\mathrm{bcd}}$ & 73 & $0.40(0.107)^{\mathrm{ab}}$ & 82 \\
Jack bean stem extract & $0.21(0.019)^{\mathrm{ab}}$ & 81 & $0.37(0.048)^{\mathrm{a}}$ & 92 \\
P-value & $<0.001$ & & $<0.001$ & \\
LSD & 0.073 & & 0.143 & \\
CV\% & 23.7 & & 27.8 & \\
\hline
\end{tabular}

N.B. Data were ${ }^{3} \sqrt{x}$ transformed. Untransformed data is shown in brackets. Means followed by the same letter in the same column do not differ significantly at $\mathrm{p}<0.05$

\subsection{Visual assessments}

\subsubsection{Goosegrass}

The results of the visual assessment of the toxicity on goosegrass of the different herbicidal treatments done using the ALAM scale are shown in Table 7. There were no significant differences $(p>0.05)$ in terms of mean ranks and median scores at 1 DAS. However, significant differences $(\mathrm{p}<0.05)$ were observed at 5 DAS. The untreated plants remained healthy whilst all the treated plants showed variable signs of phytotoxic damage. Mean ranks and median scores for goosegrass plants treated with velvet bean aqueous extracts showed no significant differences amongst treatments at 5 DAS (Table 7). The visible phytotoxic effect of velvet bean leaf, stem, and root only aqueous extracts were similar to what was observed on plants to which the atrazine control was applied. Consequently, the mean ranks and median scores at 10 DAS showed that all the treatments achieved complete weed kill by 10 DAS.

No phytotoxic effect of any treatments with jack bean aqueous extracts was observed on 1 DAS on goosegrass (Table 7). At 5 DAS all the other tissues of jack bean performed the same except the stem extracts treatment and the root + atrazine treatment which resulted in significantly lower mean ranks compared to the atrazine only treatments. At 10 DAS, the untreated plants remained healthy with a significantly low mean rank and median score of 1 but all the other treatments had already caused complete weed kill as shown by the significantly high mean ranks that ranged from $42-49$ and a uniform median score of 6 .

Figure 5 and Figure 6 show the pictorial presentation of the visual phytotoxic effects of the extracts of velvet bean and jack bean on goosegrass in comparison with atrazine + extract treatments and the controls a day before the end of the experiment. It was observed that the untreated controls remained healthy and continued growth throughout the experiments. It is interesting to note that similar activity of all the treatments was observed at about the same time in the first and second runs of the experiments. Phytotoxic activity of atrazine was observed at 4 DAS, whereas the bioherbicidal treatments started to show signs of chlorosis at 6 DAS. Symptoms that developed in all treatments were similar. The plants started to show chlorosis and necrosis starting at the tips and edges of the leaves and the upper leaves were more affected than the lower older leaves. Visually the extracts from jack bean appeared to be more phytotoxic than those from velvet bean although they caused similar symptoms on goosegrass. 
Table 7: Results of visual assessments of the percent control of goosegrass

\begin{tabular}{|c|c|c|c|c|c|c|}
\hline \multirow[b]{2}{*}{ Treatment } & \multicolumn{2}{|c|}{ Day 1} & \multicolumn{2}{|c|}{ Day 5} & \multicolumn{2}{|c|}{ Day 10} \\
\hline & $\begin{array}{l}\text { Mean } \\
\text { Rank }\end{array}$ & $\begin{array}{l}\text { Median } \\
\text { Score }\end{array}$ & $\begin{array}{l}\text { Mean } \\
\text { Rank }\end{array}$ & $\begin{array}{l}\text { Median } \\
\text { Score }\end{array}$ & $\begin{array}{l}\text { Mean } \\
\text { Rank }\end{array}$ & $\begin{array}{l}\text { Median } \\
\text { Score }\end{array}$ \\
\hline Control & 45.50 & 1.0 & $14.00^{\mathrm{a}}$ & 1.0 & $3.50^{\mathrm{a}}$ & 1.0 \\
\hline Atrazine full dose & 45.50 & 1.0 & $53.00^{\mathrm{bc}}$ & 4.0 & $49.00^{\mathrm{b}}$ & 6.0 \\
\hline Atrazine half dose & 45.50 & 1.0 & $63.50^{\mathrm{b}}$ & 4.0 & $49.00^{\mathrm{b}}$ & 6.0 \\
\hline $\begin{array}{l}\text { Velvet bean leaves }+ \\
\text { atrazine }\end{array}$ & 45.50 & 1.0 & $47.75^{\mathrm{bc}}$ & 4.0 & $49.00^{\mathrm{b}}$ & 6.0 \\
\hline Velvet bean leaves only & 45.50 & 1.0 & $58.75^{\mathrm{b}}$ & 4.0 & $49.00^{\mathrm{b}}$ & 6.0 \\
\hline Velvet bean stem + atrazine & 45.50 & 1.0 & $42.50^{\mathrm{bc}}$ & 4.0 & $49.00^{\mathrm{b}}$ & 6.0 \\
\hline Velvet bean stem & 45.50 & 1.0 & $46.08^{\mathrm{bc}}$ & 4.0 & $49.00^{\mathrm{b}}$ & 6.0 \\
\hline Velvet bean root + atrazine & 45.50 & 1.0 & $42.50^{\mathrm{bc}}$ & 3.5 & $49.00^{\mathrm{b}}$ & 6.0 \\
\hline Velvet bean root & 45.50 & 1.0 & $51.33^{\mathrm{bc}}$ & 4.0 & $49.00^{\mathrm{b}}$ & 6.0 \\
\hline Jack bean leaf + atrazine & 45.50 & 1.0 & $58.25^{\mathrm{b}}$ & 4.0 & $49.00^{\mathrm{b}}$ & 6.0 \\
\hline Jack bean leaf & 45.50 & 1.0 & $46.08^{\mathrm{bc}}$ & 4.0 & $42.00^{\mathrm{b}}$ & 6.0 \\
\hline Jack bean stem + atrazine & 45.50 & 1.0 & $46.08^{\mathrm{bc}}$ & 4.0 & $49.00^{\mathrm{b}}$ & 6.0 \\
\hline Jack bean stem & 45.50 & 1.0 & $33.92^{\mathrm{c}}$ & 3.5 & $49.00^{\mathrm{b}}$ & 6.0 \\
\hline Jack bean root + atrazine & 45.50 & 1.0 & $44.42 b^{c}$ & 4.0 & $49.00^{\mathrm{b}}$ & 6.0 \\
\hline Jack bean root & 45.50 & 1.0 & $44.83^{\mathrm{bc}}$ & 4.0 & $49.00^{\mathrm{b}}$ & 6.0 \\
\hline Kruskal-Wallis value $\left(x^{2}\right)$ & 0.000 & & 28.374 & & 79.000 & \\
\hline p-value & 1.000 & & 0.013 & & 0.000 & \\
\hline df & 14 & & 14 & & 14 & \\
\hline $\mathrm{N}$ & 90 & & 90 & & 90 & \\
\hline
\end{tabular}

Note: Means followed by different letters in the same column are significantly different from each other at $\mathrm{p}<0.05$

\subsubsection{Blackjack}

The effect of the different herbicidal treatments on blackjack plants was assessed daily and the results for visual assessments done 1 DAS, 5 DAS, and 6 DAS using the ALAM visual assessment scale are shown in Table 8 . There were no treatment differences $(\mathrm{p}>0.05)$ at 1 DAS showing that the different treatments had no immediately observable effects on blackjack. At 5 DAS treatment effects were significant $(\mathrm{p}<0.05)$. However, at 5 DAS only the untreated control remained healthy without displaying symptoms of phytotoxic damage. Contrastingly, the other herbicidal treatments appeared to have caused deleterious effects on blackjack. By 6 DAS all the herbicidal treatments had caused permanent phytotoxic damage (Figure 7 and Figure 8).

Table 8: Results of visual assessments of the percent control of beggarticks

\begin{tabular}{lcccccc}
\hline \multirow{2}{*}{ Treatment } & \multicolumn{2}{c}{ Day 1 } & \multicolumn{2}{c}{ Day 5 } & \multicolumn{2}{c}{ Day 6 } \\
& $\begin{array}{c}\text { Mean } \\
\text { Rank }\end{array}$ & $\begin{array}{c}\text { Median } \\
\text { Score }\end{array}$ & $\begin{array}{c}\text { Mean } \\
\text { Rank }\end{array}$ & $\begin{array}{c}\text { Median } \\
\text { Score }\end{array}$ & $\begin{array}{c}\text { Mean } \\
\text { Rank }\end{array}$ & $\begin{array}{c}\text { Median } \\
\text { Score }\end{array}$ \\
\hline Control & 30.50 & 1.0 & $2.5^{\mathrm{a}}$ & 1.0 & $2.50^{\mathrm{a}}$ & 1.0 \\
Atrazine full dose & 30.50 & 1.0 & $16.5^{\mathrm{b}}$ & 5.0 & $32.50^{\mathrm{b}}$ & 6.0 \\
Atrazine half dose & 30.50 & 1.0 & $16.5^{\mathrm{b}}$ & 5.0 & $32.50^{\mathrm{b}}$ & 6.0 \\
Velvet bean leaves + atrazine & 30.50 & 1.0 & $44.5^{\mathrm{c}}$ & 6.0 & $32.50^{\mathrm{b}}$ & 6.0 \\
Velvet bean leaves only & 30.50 & 1.0 & $16.5^{\mathrm{b}}$ & 5.0 & $32.50^{\mathrm{b}}$ & 6.0 \\
Velvet bean stem +atrazine & 30.50 & 1.0 & $44.5^{\mathrm{c}}$ & 6.0 & $32.50^{\mathrm{b}}$ & 6.0 \\
Velvet bean stem & 30.50 & 1.0 & $16.5^{\mathrm{b}}$ & 5.0 & $32.50^{\mathrm{b}}$ & 6.0 \\
Velvet bean root + atrazine & 30.50 & 1.0 & $44.5^{\mathrm{c}}$ & 6.0 & $32.50^{\mathrm{b}}$ & 6.0 \\
Velvet bean root & 30.50 & 1.0 & $44.5^{\mathrm{c}}$ & 6.0 & $32.50^{\mathrm{b}}$ & 6.0 \\
Jack bean leaf + atrazine & 30.50 & 1.0 & $44.5^{\mathrm{c}}$ & 6.0 & $32.50^{\mathrm{b}}$ & 6.0 \\
Jack bean leaf & 30.50 & 1.0 & $16.5^{\mathrm{b}}$ & 5.0 & $32.50^{\mathrm{b}}$ & 6.0 \\
\hline
\end{tabular}




\begin{tabular}{lcccccc}
\hline Jack bean stem + atrazine & 30.50 & 1.0 & $44.5^{\mathrm{c}}$ & 6.0 & $32.50^{\mathrm{b}}$ & 6.0 \\
Jack bean stem & 30.50 & 1.0 & $16.5^{\mathrm{b}}$ & 5.0 & $32.50^{\mathrm{b}}$ & 6.0 \\
Jack bean root + atrazine & 30.50 & 1.0 & $44.5^{\mathrm{c}}$ & 6.0 & $32.50^{\mathrm{b}}$ & 6.0 \\
Jack bean root & 30.50 & 1.0 & $44.5^{\mathrm{c}}$ & 6.0 & $32.50^{\mathrm{b}}$ & 6.0 \\
Kruskal-Wallis value $\left(x^{2}\right)$ & 0.000 & & 59000 & & 59.000 & \\
p-value & 1.000 & & 0.000 & & 0.000 & \\
df & 14 & & 14 & & 14 & \\
$\mathrm{n}$ & 60 & & 60 & & 60 & \\
\hline
\end{tabular}

Note: Means followed by the same letter in the column are not significantly different from each other at $\mathrm{p}<0.05$

Figure 7 and Figure 8 show the visual effect of the extracts of jack bean on blackjack. All the extracts performed equally to atrazine. However, during the experiment, it was observed that atrazine acted faster than all the other tissue treatments. Plants sprayed with atrazine showed signs of phytotoxic damage at 3 DAS compared to the others which caused chlorosis of leaves as from day 6. Similar findings were observed when the experiment was repeated. Generally, the effects of jack bean and velvet bean extracts were more apparent and developed faster on blackjack than on goosegrass.

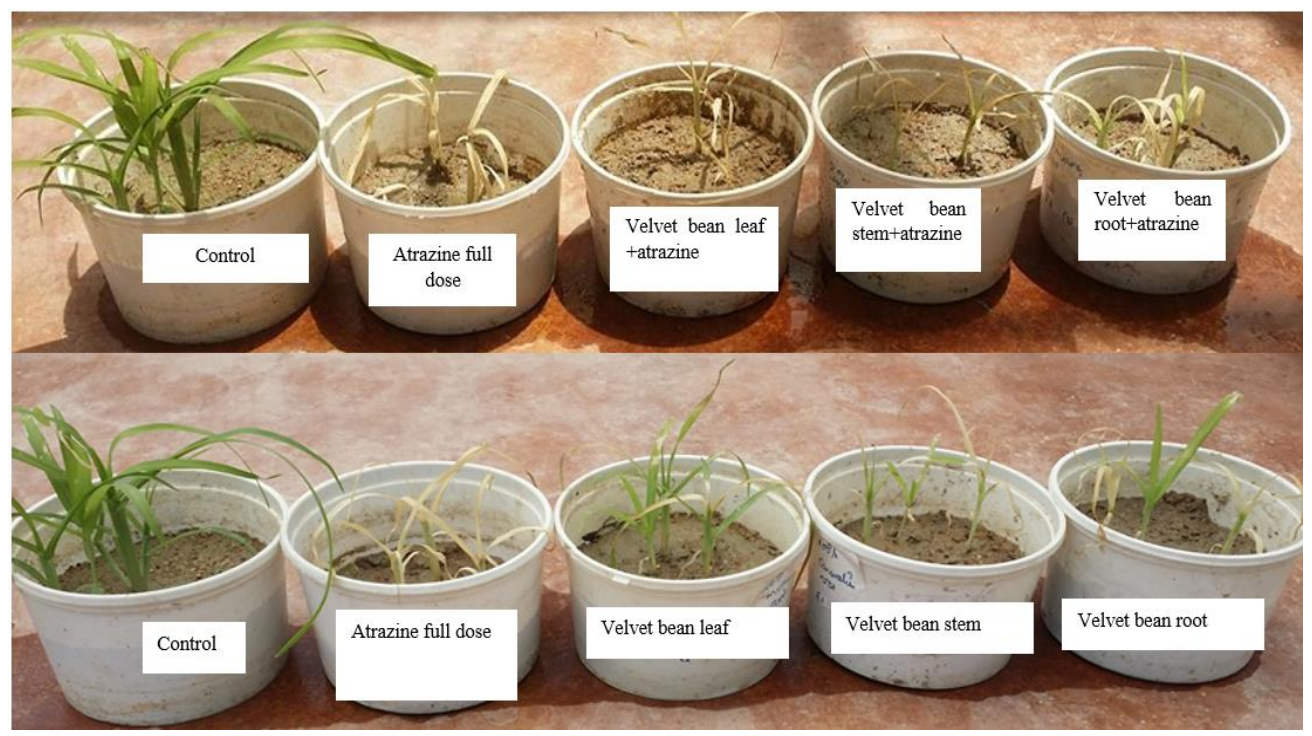

Figure 5: Phytotoxic effects of tank mixtures of atrazine and aqueous extracts of velvet bean on goosegrass 9 days after spraying 


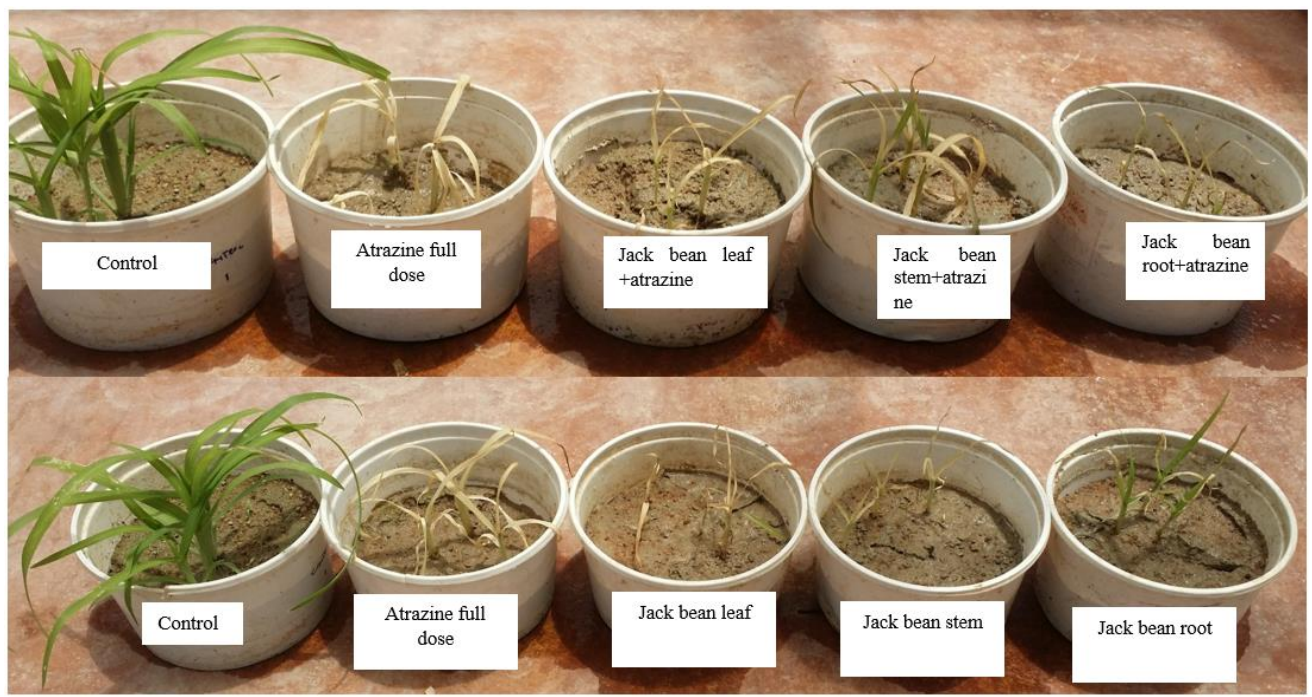

Figure 6: Phytotoxic effects of tank mixtures of atrazine and aqueous extracts of jack bean on goosegrass 9 days after spraying

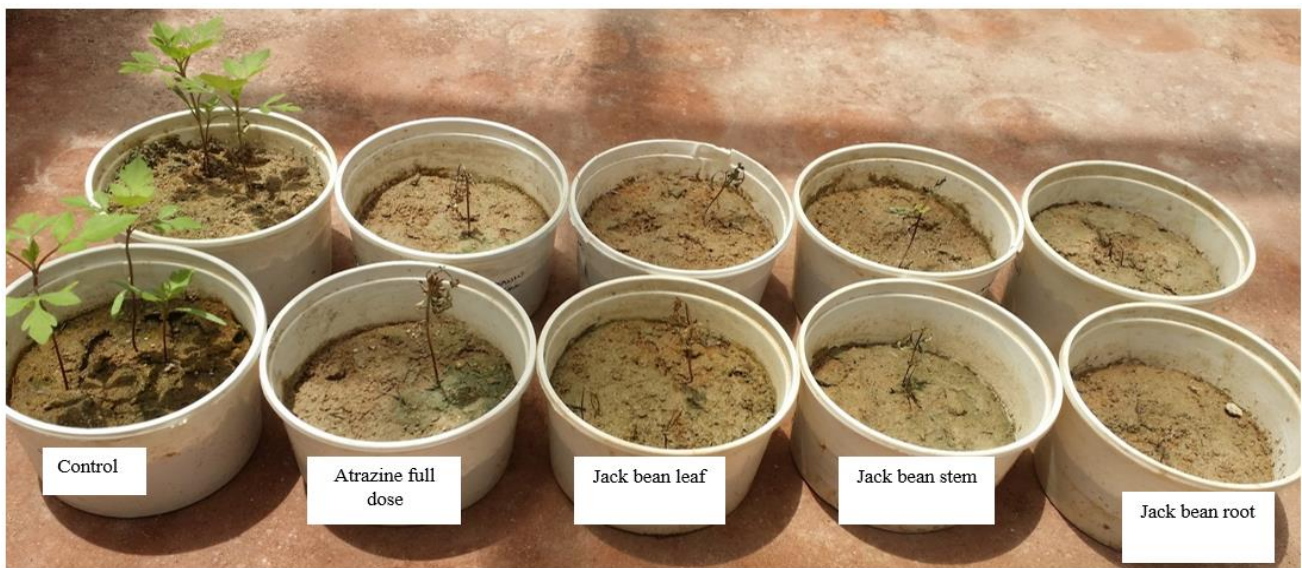

Figure 7: Phytotoxic effects of leaf, stem and root extracts of jack bean versus the untreated and atrazine control of beggarticks

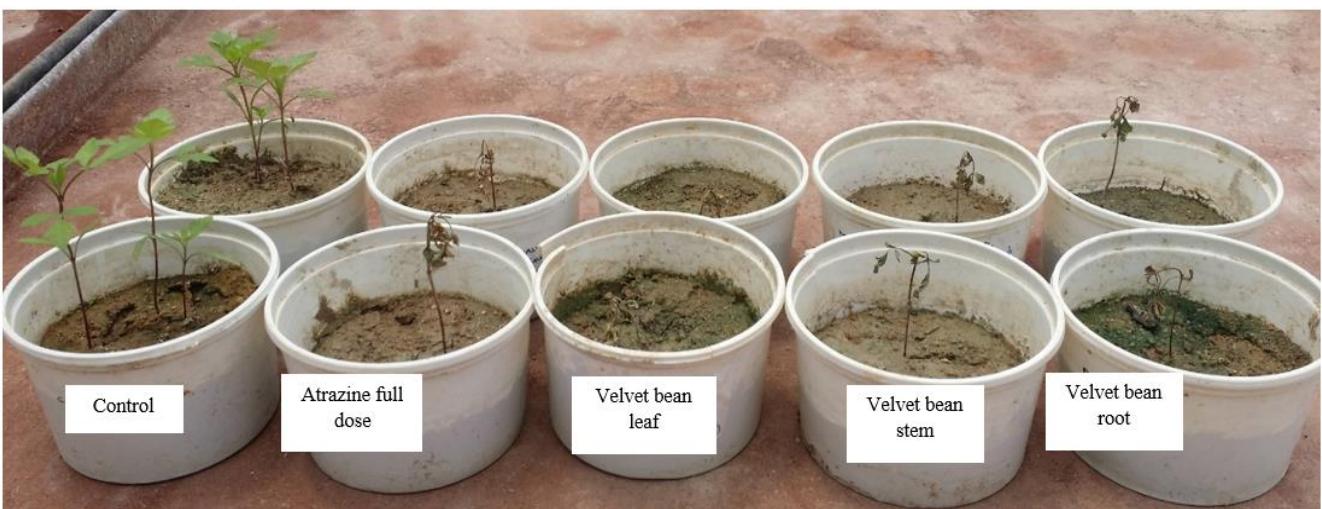

Figure 8: Phytotoxic effects of leaf, stem and root extracts of velvet bean versus the untreated and atrazine full dose controls on beggarticks 


\section{DISCUSSION}

Post-emergence application of aqueous extracts of jack bean and velvet bean did not affect the height and chlorophyll content of maize plants. Maize height increased across all the treatments indicating that the growth of maize plants was not adversely affected by the allelochemicals present in the tissues of the two cover crops. Moreover, there was an increase in maize chlorophyll content from 24 DACE to 34 DACE across all the treatments suggesting that the aqueous extracts of jack bean and velvet bean did not affect the photosynthetic pigment system of maize. Khan et al. (2012) reported similar findings when maize was sprayed using atrazine tank mixes with sorghum [Sorghum bicolor (L.) Moench], sunflower (Helianthus annuus L.), brassica, and mulberry (Morus rubra L.) extract. These results also support the findings of Dinardo et al. (1998) who reported that maize was not affected by soil incorporated biomass of jack bean tissue extracts. It was also reported that the allelochemical L3,4-dihydroxyphenylalanine (L-DOPA) found in velvet bean did not exhibit deleterious effects on maize when residues of an L-DOPA containing cover crop were used as mulch (Adediran et al., 2004). Selective weed control using allelopathic extracts on their own or with reduced herbicide dosages applied as post-emergence sprays have also been reported in wheat (Triticum aestivum L.) (Razzaq et al., 2010) and canola (Brassica napus L.) (Jabran et al., 2008). This lends credence to the fact that allelochemicals produced by jack bean and velvet bean could be selective and are likely to offer prospects for use to selectively control weeds of divergent morphology in maize.

Variable responses of different plant species to allelochemicals have been reported. For example, plants belonging to the Gramineae family to which maize belongs were seen to be less affected by L-DOPA due to their ability to detoxify this allelochemical (Soares et al., 2014). Offen et al. (2001) reported that L-DOPA could be enzymatically decarboxylated by L-DOPA decarboxylase to form dopamine or form 3-O-methyldopa through the action of catechol-O-methyltransferase. However, these findings contradict the findings of Caamal et al. (2001) who reported the phytotoxic activity of aqueous extracts of fresh velvet bean extracts on maize. The results obtained where aqueous extracts of jack bean and velvet bean were applied are similar to those where atrazine was applied suggesting that the cover crop aqueous extracts were phytotoxic to the test species. Atrazine is a pre- and early post-emergence s-chlorotriazine herbicide that is applied to selectively control mainly broadleaved weeds and some grasses in maize and other grass crops (Ross and Lembi, 1985). It is well documented that maize is tolerant to atrazine. This tolerance is due to the ability of the maize plants to enzymatically detoxify atrazine. Two enzymes, namely cytochrome P450 monooxygenase and glutathione-s-transferase, catalyse the conversion of atrazine to the nonphytotoxic conjugates $\mathrm{OH}-2$ atrazine and glutathione-atrazine that are responsible for conferring tolerance of maize to this herbicide (Ibrahim et al., 2013). Probably, the same enzymes could also enzymatically detoxifying potent allelochemicals produced by jack bean and velvet bean.

In contrast, aqueous extracts of jack bean reduced chlorophyll content and dry weight of both blackjack and goosegrass. All the herbicidal treatments caused gradual chlorosis, necrosis, and death of plant leaves. The visual effects of the extracts were similar to what was observed in the atrazine treatments. Symptom development was more visible in the youngest and top leaves, which are the ones that were more exposed to herbicide sprays. Also, symptoms developed first at the tips and edges of the affected plants which are characteristic of apoplastically translocated photosystem 2 inhibitor herbicides (Ross and Lembi, 1985). These results concur with findings by Silva and Rezende (2016) who reported that foliar application of jack bean extracts caused chlorosis with some brown spots on soybean (Glycine max L.) plants within 24 hours after application of the bioherbicide. Inhibition of photosynthesis, decrease in chlorophyll content, enzymatic activity inhibition, and cell membrane destruction are possible mechanisms through which allelochemicals could exert their effect on susceptible species (Khan et al., 2012). Reduction of chlorophyll content, carotenoid content, plant dry weight, and other growth parameters were reported in field bindweed (Convolvulus arvensis L.) treated with $10 \mathrm{~g} \mathrm{~L}^{-1}$ of Crocus sativus L., Ricinus communis 
L., Nicotiana tabacum L., Datura inoxia Mill., Nerium oleander L., \& Sorghum vulgar Pers extracts. Furthermore, Dadkhah (2012) reported reduced chlorophyll content in Cirsium arvense (L.) Scop treated with Ephedra major Host. extracts and attributed the phytotoxic activity observed to the presence of phenolics, alkaloids, and other volatile compounds found in the leaves of $E$. major. In this study, it was not clear whether the observed chlorosis as a result of the disintegration of chlorophyll already in the plant or direct chlorophyll biosynthesis inhibition (Batish et al., 2002).

The phytotoxic activity of jack bean extracts observed in this study may be attributed to the presence of phenolic compounds; p-anisic acid, chlorogenic acid, naniringin and rutin that were found to exhibit phytotoxic activity in Commelina bengalensis L., Ipomoea grandifolia (Dammer) O'Donell (Mendes and Rezende, 2014), Emilia sonchifolia and Sida spinosa L. (Silva and Rezende, 2016). Santos et al. (2007) reported germination inhibition in Mimosa pudica L., Cassia tora L., and Cassia occidentalis L. which ranged from $45.6 \%$ to $72.4 \%$ due to the effect of the allelochemical atropine in jack bean root extracts. Hence, the results obtained in this study further confirm the allelopathic activity of jack bean allelochemicals on broad-leaved plants.

Similar results were obtained in experiments where goosegrass, an annual grass weed belonging to the Poacea family was also used as a test weed species. The fact that jack bean aqueous extracts exhibited phytotoxic activity on both dicotyledonous and monocotyledonous weeds suggests the presence of allelochemicals that have a broad spectrum of activity. To our knowledge, the allelopathic activity of post-emergence sprays of both jack bean and velvet bean aqueous extracts on grass weed species has not yet been reported. Herbicide activity is known to be dosagedependent and the current lack of phytotoxic activity of extracts in maize could probably be due to subtoxic dosages of the potent allelochemicals. These results imply that $5 \% \mathrm{wv}^{-1}$ sole aqueous extracts of jack bean can effectively control annual broad-leaved and narrow-leaved weeds in maize. Moreover, allelochemicals are known to be less stable and are therefore less likely to affect rotational crops especially in $\mathrm{CA}$ and organic farming where crop rotations are a key cultural component in integrated weed management (Farooq et al., 2011). In addition, the utilisation of allelopathic aqueous extracts as post-emergence sprays has prospects to perform better than when residues are used because their efficacy is less likely to be compromised by edaphic factors. ElShahawy and Abdelhamid (2013) reported a loss of allelopathic activity of cover crop residues due to processes like enzymatic modification and adsorption especially in soils with high biological activity and cation exchange capacity (CEC). This is less likely to occur when extracts are applied post-emergence because they are readily absorbed by the foliage of the plant before they are broken down due to environmental factors.

Velvet bean also exhibited similar effects as where jack bean extracts were used. Extracts from all tissues exhibited phytotoxic activity on both weeds suggesting the presence of potent allelochemicals in leaves, stems, and roots of velvet bean. The phytotoxic activity of velvet bean on weeds has been previously reported (Adler and Chase, 2007; Runzika et al., 2013). The reduction in growth consequently causes reduced biomass accumulation in susceptible plants (Soares et al., 2014). In this study, all the tissues of velvet bean were equally phytotoxic to both weed species. Velvet bean extracts reduced chlorophyll content of both weeds. The effects of velvet bean extracts reported in this study align with the findings of Bernard and Udensi (2015) who reported the adverse effects of L-DOPA on chlorophyll synthesis in the plants. However, the effects of velvet bean extracts were faster and more devastating in blackjack than in goosegrass. These findings corroborate the work of Nishihara et al. (2005) who reported that velvet bean extracts had a more deleterious effect, on broadleaved weeds than on grass species. Similarly, Uddin et al. (2009) reported that broadleaf weeds were more susceptible to the herbicidal activity of sorgoleone than grass weed species. These observations suggest that the degree of phytotoxic damage due to allelochemicals from other plants could be species-specific (Nekonam et al., 2013). 
Results suggest that both jack bean and velvet bean are promising sources of bio-herbicides that can be applied postemergence to control weeds in sustainable agricultural systems. It has been reported that the application of allelopathic plant extracts as bio-herbicides may be a sustainable weed control strategy because they are usually less stable and have short half-lives (Dinardo et al., 1998; Farooq et al., 2011). However, their use alone may not translate into a meaningful yield benefit indicating the need to mix them with reduced dosages of herbicides (Al-Obaidi and Alsaadawi, 2015). In this study, a combination of cover crop tissue extracts and atrazine gave similar results to atrazine at a full dose. Similar results were obtained by Cheema et al. (2003). Sole extracts treatments also controlled weeds at a similar rate as treatments with synthetic herbicides. Similar findings were also obtained by several researchers working with sorghum aqueous extracts (Cheema et al., 2003, Cheema et al., 2004). It, therefore, implies that satisfactory weed control can be achieved without applying full atrazine dosages in maize. The reduced application of atrazine will enhance the provision of an economically benign strategy of managing weeds at the same time reducing environmental pollution caused by this persistent herbicide with a half-life of 60 days in the soil (Ross and Lembi, 1985). While a lot of researchers have obtained successful results from allelopathic plants applied as post-emergence natural herbicides, there still exists the need to establish the optimum concentrations and conditions under which this weed control strategy could be employed under large scale arable crop production (Weston et al., 2013).

In this study, it was shown that all the tissue extracts of both jack bean and velvet bean exhibited phytotoxic activity on blackjack and goosegrass as shown by the differences in chlorophyll content between herbicidal treatment and the untreated control on the last day of the experiment. Interestingly, the herbicidal effects of the extracts that were demonstrated on the weeds were not observed in maize. Moreover, the results demonstrated that there was no extra benefit that was gained by combining aqueous extracts of the cover crops with reduced atrazine dosages. This is an important result because it demonstrated the potential use of these allelopathic aqueous extracts for weed control without the need for synthetic herbicides. The results show that the two cover crops have the potential to be used as post-emergence sprays in maize to effectively control emerged weed seedlings even without combining them with atrazine.

\section{CONCLUSION}

It could be concluded that both jack bean and velvet bean leaf, stem, and root tissues possess allelochemicals that have post-emergence herbicidal effects on blackjack and goosegrass, while maize is rather insensitive. It can, therefore, be further concluded that $5 \% \mathrm{wv}^{-1}$ aqueous extracts of the leaf, stem, and root tissues of jack bean and velvet bean can be used to effectively control annual weed seedlings in maize. These findings provide a reasonable base for suggesting that the use of jack bean and velvet bean aqueous extracts as post-emergence sprays could provide an effective and environmentally friendly method of weed control. However, there is a need to evaluate the efficacy of these extracts under field conditions in different soils and agro-ecological regions. There could also be merit in evaluating the allelopathic activity of these two cover crops on other important and commonly occurring weeds in maize production and other crops. Economic analysis may also need to be done to establish the economic feasibility of using these bioherbicides in weed management as well as establishing the optimum application rate of these extracts.

Funding: Funds for this research were provided by a capacity-building competitive grant training the next generation of scientists provided by Carnegie Cooperation of New York through the Regional Universities Forum for Capacity Building in Agriculture (RUFORUM).

Competing Interests: The authors declared that they have no conflict of interests.

Contributors/Acknowledgement: All authors participated equally in the research.

Views and opinions expressed in this study are the views and opinions of the authors, Asian Journal of Agriculture and Rural Development shall not be responsible or answerable for any loss, damage or liability, etc. caused in relation to/arising out of the use of the content. 


\section{References}

Adediran, J. A., Akande, M. O., \& Oluwatoyinbo, F. I. (2004). Effect of mucuna intercropped with maize on soil fertility and yield of maize. Ghana Journal of Agricultural Science, 37, 15-22. doi.org/10.4314/gjas.v37i1.2075.

Adler, J. M., \& Chase, A. C. (2007). Comparison of the allelopathic potential of leguminous summer cover crops: Cowpea, sunn hemp and velvet bean. Hort Science, 42, 289-293. doi.org/10.21273/hortsci.42.2.289.

Al-Obaidi, L. Z., \& Alsaadawi, I. S. (2015). Combining effect of different rates of Sorghum bicolor (L.) Moench residues and reduced rates of trifluralin on weeds in mung bean field. Iraqi Journal of Science, 56, 1622-1632.

Amaral, A., \& Takaki, M. (1998). Achene dimorphism in Bidens pilosa L. as determined by germination test. Brazilian Archives of Biology and Technology, 41, 10-15. doi.org/10.1590/s1516-89131998000100002.

Ashburner, J. E. (1984). Dryland tillage practices and studies in Algeria. F.A.O. panel of experts on agricultural mechanization, $6^{\text {th }}$ session, Adana, Turkey, October 1984.22pp.

Batish, D. R., Sigh, H. P., Kohli, R. K., Saxena, D. B., \& Kaur, S. (2002). Allelopathic effects of parthenin against two weedy species, Avena fatua and Bidens pelota. Environmental and Experimental Botany, 47, 149-155. doi.org/10.1016/s0098-8472(01)00122-8.

Bernard, O. E., \& Udensi, U. E. (2015). Evaluation of potential allelopathic relationship between velvet bean (Mucuna cochinchinensis (Lour.) A. Chev) and Speargrass [Imperata cylindrical (L.) Raeushel] with selected methods. Journal of Agriculture and Ecology Research International, 3, 89-96. doi.org/10.9734/jaeri/2015/15450.

Caamal, M. J. A., \& Jimenez, O. J. J., Torres, B. H., \& Anaya, A. L. (2001). The use of allelopathic legume cover and mulch species for weed control in cropping systems. Agronomy Journal, 93, 27-36. doi.org/10.2134/agronj2001.93127x.

Chauran, B. S., Singh, R. C., \& Mahajan, G. (2012). Ecology and management of weeds under conservation agriculture: a review. Crop Protection, 38, 57-65. doi.org/10.1016/j.cropro.2012.03.010.

Cheema, Z. A., Khichi, A. H., \& Khaliq, A. (2005). Feasibility of reducing herbicide dose in combination with sorgaab for weed control in transplanted fine rice (Oryza sativa L.). International Journal of Agricultural Biology, 7, 892-894.

Cheema, Z. A., Khaliq, A., \& Saeed, S. (2004). Weed control in maize (Zea mays L.) through sorghum allelopathy. Journal of Sustainable Agriculture, 23, 73-86.

Cheema, Z. A., Khaliq, A., \& Mubeen, M. (2003). Response of wheat and winter weeds to foliar application of different plant water extracts of Sorghum (Sorghum bicolor). Pakistan Journal of Weed Science Research, 9, 89-97. doi.org/10.28941/24-1(2018)-2.

Dadkhah, A. (2012). Allelopathic effect of Ephedra major on growth and photosynthesis of Cirsium arvense weed. International Journal of Agriculture, 2, 416-419. doi.org/10.5513/jcea01/20.4.2047.

Derpsch, R. (2008). No tillage and conservation agriculture: A progress report. In: Goddard T, Zoebisch M, Gan Y, Ellis E, Watson A, Sombatpanit S (eds). No till Farming Systems. Special publication No. 3. The World Association of Soil and Water Conservation, Bangkok,

Dinardo, W., Pellergrini, M. T., \& Alves, P. L. C. A. (1998). Inhibitory effects of Jack bean (Canavalia ensiformis L.) leaf residues on the germination and vigor of crops and weeds. Allelopathy Journal, 5, 35-42.

El-Shahawy, T. A., \& Abdelhamid, M. T. (2013). Potential allelopathic effect of six Phaseolus vulgaris recombinant inbred lines for weed control. Australian Journal of Basic and Applied Sciences, 7, 462-467.

Farooq, M., Jabran, K., Cheema, Z. A., Wahid, A., \& Siddique, K. H. M. (2011). The role of allelopathy in agricultural pest management. Pest Management Science, 67, 493-506. doi.org/10.1002/ps.2091. 
Fujii, Y. T. (1999). Allelopathy of hairy vetch and mucuna: their applications for sustainable agriculture. In: Chou $\mathrm{CH}$, Waller GR, Reinhardt C (eds). Biodiversity and allelopathy from organisms to ecosystems in the pacific. Academia Sinica, Taipei, pp. 289-300.

Reinhardt, C. F. (1995). Residual effect of atrazine on field-grown dry beans and sunflower. South African Journal of Plant and Soil, 12(2), 82-85. doi.org/10.1080/02571862.1995.10634341.

Harrington, L., \& Erenstein, O. (2005). Conservation agriculture and resource conserving technologies-A global perspective. Agromeridian, 10, 32-43.

Helling, C. S., Zhuang, W., Gish, T. J., Coffman, C. B., Isensee, A. R., Kearney, P. C., \& Woodward, M. D. (1988). Persistence and leaching of atrazine, alachlor, and cyanazine under no-tillage practices. Chemosphere, 17, 175-187. doi.org/10.1016/0045-6535(88)90055-0.

Hobbs, P. R. (2007). Conservation agriculture: what is it and why is it important for future sustainable food production? Journal of Agricultural Science, 145, 127-137.

Ibrahim, S. I., Abdel Lateef, M. F., Khalifa, H. M. S., Abdel, M. A. E. (2013). Phytoremediation of atrazine contaminated soil using maize (Zea mays L.). Annals of Agricultural Science, 58, 6975.

Jabran, K., Cheema, Z. A., Farooq, M., Basra, S. M. A., Hussain, M., \& Rehman, H. (2008). Tank mixing of allelopathic crop water extracts with pendimethalin helps in the management of weeds in canola (Brassica napus) field. International Journal of Agricultural Biology, 10, 293-296. doi.org/10.31220/osf.io/4h2kg.

Jat, R. A., Wani, S. P., \& Sahrawat, K. L. (2012). Conservation agriculture in the semi-arid tropics: prospects and problems. Advances in Agronomy, 117, 191-273. doi.org/10.1016/b978-0-12394278-4.00004-0.

Khan, M. B., Ahmud, M., Hussain, M., Jabran, K., Farooq, S., \& Wasqas-Ul-Haq, M. (2012). Allelopathic plant water extracts tank mixed with reduced doses of atrazine efficiently control Trianthema portulacastrum L. in Zea mays L. The Journal of Animal and Plant Sciences, 22, 339-346.

Mashingaidze, N., Madakadze, I. C., \& Twomlow, S. (2012). Response of weed flora to conservation agriculture systems and weeding intensity in semi-arid Zimbabwe. African Journal of Agricultural Research, 7, 5069-5082. doi.org/10.5897/ajar12.020.

Mendes, I. D. S., \& Rezende, M. O. O. (2014). Assessment of the allelopathic effect of leaf and seed extracts of Canavalia ensiformis as post-emergent bio-herbicides: A green alternative for sustainable agriculture. Journal of Environmental Science and Health, 49, 374-380. doi.org/10.1080/03601234.2014.882179.

Miri, H. R., \& Armin, M. (2013). The use of plant water extracts in order to reduce herbicide application in wheat. European Journal of Experimental Biology, 3, 155-164.

Muoni, T., Rusinamhodzi, L., Mabasa, S., Rugare, J. T., \& Thierfelder, C. (2014). Does the use of atrazine in maize grown under conservation agriculture adversely affect soybean productivity in maize-soya bean rotations in Zimbabwe? Journal of Agricultural Science, 6, 1-7. doi.org/10.5539/jas.v6n7p294.

Nekonam, M. S., Razmjoo, J., Sharifnabi, B., \& Karimojeni, H. (2013). Assessment of allelopathic plants for their herbicidal potential against field bindweed (Convolvulus arvensis). Australian Journal of Crop Science, 7, 1654-1660.

Nishihara, E., Parvez, M. M., Araya, H., \& Kawashima, S. (2005). L-3-(3, 4-Dihydroxyphenyl) alanine (L-DOPA) an allelochemical exuded from velvet bean (Mucuna pruriens) roots. Plant Growth Regulation, 45, 113-120.

Offen, D., Panet, H., Galili-Mosberg, R., \& Melamed, E. (2001). Catechol-O-methyltransferase decreases levodopa toxicity in vitro. Clinical Neuropharmacology, 24, 27-30. doi.org/10.1097/00002826-200101000-00006.

Pieterse, P. J. (2010). Herbicide resistance in weeds-a threat to effective chemical weed control in South Africa. South African Journal of Plant and Soil, 27, 68-73. doi.org/10.1080/02571862.2010.10639971. 
Razzaq, A., Cheema, Z. A., Jabran, K., Farooq, M., Khaliq, A., Haider, G., \& Basra, S.M.A. (2010). Weed management in wheat through combination of allelopathic water extracts with reduced doses of herbicides. Pakistan Journal of Weed Science Research, 16, 247-256.

Razzaq, A., Cheema, Z. A., Jabran, K., Hussain, M., Farooq, M., \& Zafar, M. (2012). Reduced herbicide doses used together with allelopathic sorghum and sunflower water extracts for weed control in wheat. Journal of Plant Protection Research, 52, 281-285. doi.org/10.2478/v10045-012-0045-0.

Ross, M. A., \& Lembi, C. A. (1985). Applied weed science. Burgess Publishing Company, Minneapolis, United States of America.

Rugare, J. T., Pieterse, P. J., \& Mabasa, S. (2019). Effect of short-term maize-cover crop rotations on weed emergence, biomass and species composition under conservation agriculture. South African Journal of Plant and Soil, 36(5), 329-337. doi.org/10.1080/02571862.2019.1594419.

Rugare, J. T., \& Mabasa, S. (2013). Efficacy and economics of manual and chemical weed control strategies in the first year of conservation agriculture adoption in the Highveld areas of Zimbabwe. Global Advanced Research Journal of Agricultural Science, 2, 231-241.

Runzika, M., Rugare, J. T., \& Mabasa, S. (2013). Screening green manure cover crops for their allelopathic effects on some important weeds found in Zimbabwe. Asian Journal of Agriculture and Rural Development, 3, 554-565.

Santos, S., Moraes, M. L. L., \& Rezende, M. O. O. (2010). Determination of polyamines in organic extracts from roots of Canavalia ensiformis by capillary electrophoresis. Journal of Environmental Science and Health, 45(4), 325-329. doi.org/10.1080/03601231003704481.

Santos, S., Moraes, M. L. L., \& Rezende, M. O. O. (2007). Allelopathic potential and systematic evaluation of secondary compounds in extracts from roots of Canavalia ensiformis by capillary electrophoresis. Ecletica Quimica, 32, 13-18.

Sayre, K., Govaerts, B., Martinez, A., Mezzalama, M., \& Matinez, M. (2006). Effect of tillage practices and planting patterns on performance of white bean (Phaseolus vulgaris L.) in Ontario. Canadian Journal of Plant Science, 74, 801-805. doi.org/10.4141/cjps94-143.

Silva, D. F., \& Rezende, M. O. O. (2016). Microwave-assisted extraction of phenolics compounds from Canavalia ensiformis leaves: preparation and evaluation of prospective bio-herbicide on control of soya bean weeds. International Journal of Engineering and Applied Sciences, 3, 106-111.

Singh, A., \& Ghoshal, N. (2013). Impact of herbicide and various soil amendments on soil enzyme activities in a tropical rain fed agro ecosystem. European Journal of Soil Biology, 54, 56-62.

Soares, A. R., Marchiosi, R., Siqueira, S., R. C., Barbosa, de L. R., Dantas, dos S. W., \& Ferrarese, F. O. (2014). The role of L-Dopa in plants. Plant Behavior and Signaling, 9, 1-7.

Soltys, D., Krasuska, U., Bogatek, R., \& Gniazdowska, A. (2013). Allelochemicals as bioherbicides-present and perspectives. In: Price AJ, Kelton JA (eds). Herbicides-current research and case studies in use. In Tech, 18, 517-542.

Uddin, M. R., Kim, Y. K., Park, S. U., \& Pyon, J. Y. (2009). Herbicidal activity of sorgoleone from grain sorghum root exudates and its contents among sorghum cultivars. Korean Journal of Weed Science, 29, 229-236.

Wall, P. (1999). Experiences with crop residue cover and direct seeding in the Bolivian highlands. Mountain Research and Development, 19, 313-317.

Weston, L. A., Alsaadawi, I. S., \& Bearson, S. C. (2013). Potential and prospects of sorghum allelopathy in agroecosystems. Allelopathy Journal, 24, 255-270. 